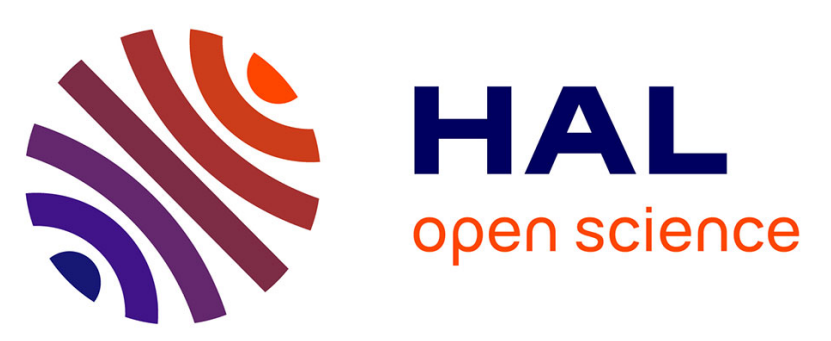

\title{
Monitoring PAH contamination in the field (South west Iberian Peninsula): biomonitoring using fluorescence spectrophotometry and physiological assessments in the shore crab (L.) (Crustacea: Decapoda)
}

Awantha Dissanayake, Shaw D. Bamber

\section{To cite this version:}

Awantha Dissanayake, Shaw D. Bamber. Monitoring PAH contamination in the field (South west Iberian Peninsula): biomonitoring using fluorescence spectrophotometry and physiological assessments in the shore crab (L.) (Crustacea: Decapoda). Marine Environmental Research, 2010, 70 (1), pp.65. 10.1016/j.marenvres.2010.03.003 . hal-00598202

\section{HAL Id: hal-00598202 \\ https://hal.science/hal-00598202}

Submitted on 5 Jun 2011

HAL is a multi-disciplinary open access archive for the deposit and dissemination of scientific research documents, whether they are published or not. The documents may come from teaching and research institutions in France or abroad, or from public or private research centers.
L'archive ouverte pluridisciplinaire HAL, est destinée au dépôt et à la diffusion de documents scientifiques de niveau recherche, publiés ou non, émanant des établissements d'enseignement et de recherche français ou étrangers, des laboratoires publics ou privés. 


\section{Accepted Manuscript}

Title: Monitoring PAH contamination in the field (South west Iberian Peninsula): biomonitoring using fluorescence spectrophotometry and physiological assessments in the shore crab Carcinus maenas (L.) (Crustacea: Decapoda)

Authors: Awantha Dissanayake, Shaw D. Bamber

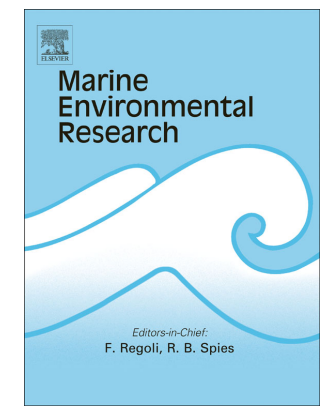

PII: S0141-1136(10)00043-7

DOI: 10.1016/j.marenvres.2010.03.003

Reference: MERE 3430

To appear in: Marine Environmental Research

Received Date: 12 January 2010

Revised Date: 24 February 2010

Accepted Date: 4 March 2010

Please cite this article as: Dissanayake, A., Bamber, S.D. Monitoring PAH contamination in the field (South west Iberian Peninsula): biomonitoring using fluorescence spectrophotometry and physiological assessments in the shore crab Carcinus maenas (L.) (Crustacea: Decapoda), Marine Environmental Research (2010), doi: 10.1016/j.marenvres.2010.03.003

This is a PDF file of an unedited manuscript that has been accepted for publication. As a service to our customers we are providing this early version of the manuscript. The manuscript will undergo copyediting, typesetting, and review of the resulting proof before it is published in its final form. Please note that during the production process errors may be discovered which could affect the content, and all legal disclaimers that apply to the journal pertain. 
Monitoring PAH contamination in the field (South west Iberian Peninsula): biomonitoring using fluorescence spectrophotometry and physiological assessments in the shore crab Carcinus maenas (L.) (Crustacea: Decapoda)

Awantha Dissanayake ${ }^{* 1}$ and Shaw D. Bamber ${ }^{2}$

${ }^{1}$ Institute for East China Sea Research, Nagasaki University, Tairamachi 1551-7, Nagasaki 851-2213, Japan.

${ }^{2}$ IRIS Biomiljø, Mekjarvik 12, N - 4070 Randaberg, Norway

$*=$ corresponding author.

E-mail: awantha@nagasaki-u.ac.jp 


\section{ABSTRACT}

Polycyclic aromatic hydrocarbons (PAHs) are ubiquitous pollutants of the marine environment, arising predominantly from petrochemical contamination and pyrogenic sources. A biomarker of PAH exposure was employed in a field study (South West, Spain) in both captured (indigenous) and deployed (caged) shore crabs (Carcinus maenas) in the chronic PAH-exposed Bays of Algeciras and Gibraltar (from associated harbour and boating activity) compared to a relatively 'clean' site (Cadiz). Metabolite fluorescence was attributed to the following key priority $\mathrm{PAH}$ groups; naphthalenes (NAPs), pyrenes (PYRs) and benzo[a]pyrenes (BAPs). Temporal variability was assessed using deployed populations over an eight week period. Petrogenic and pyrogenic PAH contamination (as an indicator of the $\mathrm{PAH}$ type) was demonstrated using a ratio between $\mathrm{FF}_{\mathrm{BAP}+\mathrm{PYR}} / \mathrm{FF}_{\mathrm{NAP}}$. Physiological assessments from deployed crabs demonstrated both physiological and cellular alterations as shown by reduced heart rates (at rest) and increased cellular stress in crabs from the PAH contaminated sites.

Key words: Polycyclic aromatic hydrocarbon (PAH), Carcinus maenas, fluorescence spectrophotometry, Gibraltar. 


\section{INTRODUCTION}

Coastal marine waters and sediments receiving anthropogenic inputs can contain a large variety of contaminants that are potentially toxic to aquatic organisms (Krahn et al., 1984) (Kennish, 2002). One group of chemicals of particular concern are the highly lipophilic polycyclic aromatic hydrocarbons (PAHs), which are ubiquitous pollutants of the marine environment. These compounds arrive in coastal waters from a diverse array of sources including petrochemical pollution, incomplete combustion processes (Livingstone, 1992; Clarke et al., 2001), metal smelting (Naes et al., 1995; Beyer et al., 1996) and electrolytic production of aluminium using anode technology (Beyer et al., 1998; Aas et al., 2000b; MSC-E, 2001). Concern over the fate and effect of PAHs in the environment is related to their persistence, bioaccumulation potential and acute \& chronic toxicity to marine organisms. Three PAHs, naphthalenes, pyrenes \& benzo[a]pyrenes, are included in the USEPA priority pollutant list (MSC-E, 2001).

Current monitoring techniques employed to determine environmental quality include the chemical analyses of sediment and water samples. PAHs are sparingly soluble in water and are difficult to detect and although they show a much greater association with sediments, chemical analysis of this material is laborious and costly due to the lengthy extraction methodology needed. Furthermore, sediment/waterbased measurements provide little information about contaminant bioavailability and toxic potential. Routine chemical monitoring usually involves determination of the concentration of parent compounds present in the environmental phase of interest. This approach may overlook the risks posed by the potentially much more toxic daughter compounds produced by many organisms as a result of metabolism and biotransformation of the parent chemicals (Livingstone, 1998). Metabolites arising from biotransformation processes may be concentrated in body fluids, tissues or 
excreta and the analysis of such biological compartments provides us with an opportunity to detect and measure exposure of organisms to bioavailable contaminants (Fillmann et al., 2002).

The detection of $\mathrm{PAH}$ metabolites is made possible due to the fluorescence properties attributed to their delocalised $\pi$-electrons. This property was first developed for environmental monitoring purposes as a rapid, inexpensive screening method to detect PAH metabolites in fish bile and used HPLC in combination with a fluorescence detector to process test samples. This technique has subsequently been implemented as a monitoring tool in several environmental monitoring programmes (Krahn et al., 1984; Stagg, 1998; Aas et al., 2000a, 2001) and has been further developed for use in analysing the presence or absence of PAH metabolites in crustacean urine by (Watson et al. 2002). Metabolites in shore crab (Carcinus maenas) urine were analysed at specific fluorescence wavelengths for naphthalene-, pyrene- and benzo[a]pyrene-type compounds. The use of crab urine to monitor environmental contamination has proved to be a useful technique as it provides a measure of contemporary levels of contamination (Watson et al. 2004b). Fixed wavelength fluorescence (FF) method used to detect PAH metabolites has the advantage that it is less expensive than the previously-used HPLC technique and demonstrates a dose-response relationship. The aim of this study was to evaluate the use of a PAH exposure biomarker (by detection of PAH metabolites) using the decapod crustacean species Carcinus maenas to assess the extent of PAH exposure in this region, and to determine if this technique provides a cost-effective surrogate for other chemical analytical techniques. A specific objective of the study was to investigate the field application of the $\mathrm{PAH}$ exposure biomarker in crabs collected from both local natural populations and also deployed (caged) crabs. A second objective was to investigate the relationship between the presence of $\mathrm{PAH}$ metabolites in urine and selected physiological traits (cardiac activity assessed by 
heart rate measurements and monitoring cellular impact by lysosomal stability measurements) in crabs that in combination could be used to support biomonitoring programmes. Physiological assessments of invertebrates using cardiac activity (Fossi et al. 2000; Camus et al. 2002) and lysosomal stability (Lowe et al. 1994; Castro et al. 2004) measurements have been widely used in both laboratory and field scenarios (Brown et al. 2004; Galloway et al. 2004) as general "health" indicators. Lysosomal damage arises from the accumulation of PAHs, the resultant formation of oxyradicals leads to increased membrane permeability and subsequent release of acid hydrolases into the cytoplasm, causing cellular damage and/or ultimately, cell death (Lowe et al., 1995). The resulting toxic effect of PAHs is expressed through the hierarchical levels of biological organisation i.e. cellular and physiological levels (Fossi et al. 1994).

\section{MATERIALS AND METHODS}

\subsection{Study sites}

The study sites were situated in the Southwest Iberian Peninsula in the Bays of Algeciras and Gibraltar and further west in the Bay of Cadiz (Fig 1). Gibraltar is a small peninsula situated at the mouth of the Mediterranean Sea with a $30 \mathrm{~km}$ coastline. There is a heavy industrial presence from within the Bays of Algeciras and Gibraltar and an apparent lack of data concerning environmental quality with regard to specific types of contaminants within the region. The area has proximity to chemical plants, refineries, thermal power plants, ironworks, paper mills, shipyards and two major ports which serve the economically important sea route of the Straits of Gibraltar (Truver, 1978; Mavor, 1980). The Bay of Algeciras receives input from two major rivers; The Palmones and the Guadarranque, which carry sewage from urban and industrialised activities corresponding to populations of 15000 and 2500 
respectively, (Carballo et al., 1996). Polyaromatic hydrocarbons in the Bay of Algeciras indicate chronic contamination in this area $\left(21.4 \mu \mathrm{g} \mathrm{kg}^{-1}\right.$ sediment) originating from accidental spills, bunkering activities and deliberate discharges from commercial shipping (Jimenez-Tenorio et al., 2008). The Bay of Cadiz is characterised by urban and harbour activities with low sediment contamination (Cesar et al., 2007), however, the area outside the Bay of Cadiz (San Fernando) was used as the reference site as it is situated in a highly productive protected natural site where there is no urban activity (Perez et al., 2004). These particular sites were chosen due to the highly industrialised nature of the surrounding area, including the Bay of Gibraltar, which is highly populated $(31,000$ in $6 \mathrm{sq} \mathrm{Km}$ ) (United Nations, 2009) and includes two major harbours; The Port of Algeciras (Spain) and The Port of Gibraltar (Gibraltar), within a naturally enclosed area situated within the Straits of Gibraltar. There is an apparent lack of data concerning environmental quality with reference to specific types of contaminants in the Bay of Gibraltar. Based on this lack of knowledge, sites were ranked based on the degree of boating activity and

100 industrial presence; Cadiz (low: no boating activity), Palmones Estuary [intermediate:

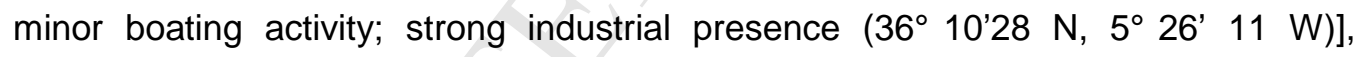
Gibraltar Harbour (middle): [intermediate boating activity (3608'13 N, 5²1' $22 \mathrm{~W})$ ], Gibraltar Harbour [inner ( $36^{\circ} 07^{\prime} 55 \mathrm{~N}, 5^{\circ} 21$ 18W)] (high: major boating activity) (Fig.1).

\subsection{Shore crab deployment and collection}

Carcinus maenas individuals (green intermoult males; carapace width 50-75 mm) sampled from the reference site [San Fernando, Cadiz, South-west Spain (36²7’53 $\left.\mathrm{N}, 6^{\circ} 1150 \mathrm{~W}\right)$ ] and were used for the deployment st udy (June - August 2001) using cages at selected field sites within the Bay of Gibraltar, Southwest Iberian Peninsula

(Fig. 1). Prior to deployment, adult individuals (> $60 \mathrm{~mm}$ ) (Crothers, 1967) were 
measured and labelled (labels attached to carapace with cyanoacrylate glue) and allowed to depurate for 14 days, fed (throughout this study with squid mantle tissue) and maintained in the laboratory in flow-through holding tanks (350 I) with filtered (10 $\mu \mathrm{m}$ carbon-filtered) seawater at similar conditions to that found at each site [salinity: $36_{P S U}$ and at ambient temperature $\left(22{ }^{\complement}\right)$ ]. Prior to dep loyment, crabs were fed to satiation. Crabs were deployed sub-tidally (approx. $4 m$ ) in plastic cages $(n=40$ cage $\left.{ }^{1}\right)$ (cage measurements: $47 \times 34.6 \times 28.7 \mathrm{~cm}$ ). The entrance of each cage was covered by mesh $(1 \mathrm{~cm})$ in order to exclude predators. Crabs were held in cages at the selected field sites (Palmones Estuary and Gibraltar Harbour sites) and fed once a week with squid. Caged shore crabs $(n=8)$ were sampled at random (JuneAugust 2001) from each cage each week over several weeks (1, 2, 4, 6 and 8). Prior to caging experiments, a preliminary test for the effects of caging was performed at the reference site (Cadiz) where shore crab physiological responses (see 2.5) were measured after one week and no significant differences were observed (heart rates: $F_{1,14}=0.6, P=0.45 ;$ lysosomal stability (neutral red retention time): $F_{1,14}=1.24, P=$ 0.28). Local indigenous populations were collected using squid-baited traps or handcollected at the various field sites in the month of June. During transportation (to field sites or the laboratory) all crabs were placed in cool boxes with icepacks and damp absorbent paper.

\subsection{Urine Extraction and Analysis}

Urine from each crab was extracted and analysed using the techniques described by

Watson et al. (2004b). In summary, crabs were physically restrained prior to urine extraction by using elastic bands to hold them securely onto to small wooden boards with their ventral surface presented uppermost. The third maxillipeds were moved aside and restrained using further elastic bands to allow access to the epistome and 
antennal gland opercula. The epistome was dried in order to prevent seawater diluting the urine. Lifting of the antennal gland opercula, with the aid of a fine hooked seeker, triggers the release of urine from restrained crabs. Extracted urine (20 $1000 \mu l)$ was transferred to siliconised micro-centrifuge tubes. All urine samples were stored at $-80^{\circ} \mathrm{C}$ until subsequent analysis.

\subsection{Spectrophotometric analysis}

Fixed fluorescence (FF) spectrometry analysis was performed on diluted urine samples (1:20) whereby there are no significant inner filter effects (Hitachi F-4500 fluorescence spectrophotometer). All FF analyses were carried out in a $3.5 \mathrm{ml}$ quartz fluorescence cuvette and performed with excitation and emission slit widths of 2.5 nm. Fluorescence contributions can be attributed to three PAH groups; 2 ring, 4 ring \& 5/6 ringed PAHs typified by naphthalene-type (NAP-type), pyrene-type (PYR-type) and benzo[a]pyrene-type (BAP-type) metabolites respectively as their behaviour is similar to other compounds of similar ring number (Reeves et al. 2004). Fluorescence analyses were not undertaken to quantify individual PAH compounds, but to discriminate between sites of varying PAH exposure (Dissanayake and Galloway, 2004). The assigned wavelength pairs and peak area measurements were used to quantify the metabolite groups as follows; $\mathrm{FF}_{290 / 335}(315-375), \mathrm{FF}_{341 / 383}$ (380-390nm) \& FF $380 / 430(400-490 \mathrm{~nm})$ for 2\&3-rings (naphthalene-type PAHs), 4-rings (pyrene-type PAHs) and 5-6 ringed PAHs respectively (benzo[a]pyrene-type PAHs). Pyrene-type metabolites only were quantified by using 1-OH pyrene standards

(Sigma, U.K). The ratio between the sum of BAP \& PYRs over NAPs $\left(\mathrm{FF}_{\mathrm{BAP}+\mathrm{PYR}} /\right.$ $\mathrm{FF}_{\mathrm{NAP}}$ ) was calculated in order to determine $\mathrm{PAH}$ contamination origin [i.e petrogenic (NAPs) or pyrogenic (PYR and BAP)]. 
A combination of physiological (heart rate measurements) and cellular endpoints were used to determine potential physiological impact. Following urine extraction, heart rate measurements were performed on shore crabs by use of the non-invasive CAPMON system (Depledge and Andersen, 1990). Heart rate measurements were

\subsection{Statistical analysis}

190 performed on individuals in $2 \mathrm{~L}$ aquaria (using water collected from each site); sensors were glued to the carapace above the heart and, after $30 \mathrm{~min}$ acclimation, cardiac activity (at rest) was recorded for $30 \mathrm{~min}$ as (as employed previously by Dissanayake et al., 2008b). Lysosomal stability (using neutral red dye) assesses the lysosomal compartment of cells where toxins (e.g. PAHs) are accumulated prior to detoxication. If the lysosomes are overloaded, damage may lead to cell injury, tissue dysfunction, and reduction in animal "health status" (Moore et al., 2004). Haemolymph was extracted by inserting a needle through the arthodial membrane at the base of the third walking leg and extracted into a syringe with 0.5 $\mathrm{ml}$ of crustacean physiological saline $\left(0.5 \mathrm{M} \mathrm{NaCl}, 11 \mathrm{mM} \mathrm{KCl}, 12 \mathrm{mM} \mathrm{CaCl} \cdot 6 \mathrm{H}_{2} \mathrm{O}\right.$, $26 \mathrm{mM} \mathrm{MgCl}_{2} \cdot 6 \mathrm{H}_{2} \mathrm{O}, 45 \mathrm{mM} \mathrm{Na} \mathrm{HPO}_{4} \cdot 12 \mathrm{H}_{2} \mathrm{O}, 45 \mathrm{mM}$ Trisma-Base, $1 \mathrm{M} \mathrm{HCl}$; pH 7.4). Cysteine (50 mg ml$\left.{ }^{-1}\right)$ was added as an anti-coagulant (Smith and Ratcliffe, 1978). Haemolymph $(40 \mu \mathrm{l})$ was transferred onto a glass slide cells were allowed to adhere in a humidity chamber (15 mins) before incubating (15 $\mathrm{min})$ with the neutral red dye. Cells were observed under a high powered microscope over time (15, 30, 60, 75, 90 $120,150,190 \mathrm{~min}$ ) and the retention of the dye within the haemocyte lysosomes was recorded (as employed by Brown et al., 2004).

Analysis of variance (ANOVA) tests were performed for the individual PAHs (NAP, PYR and BAP) physiological (heart rates) and cellular (NRR) endpoints (transformed where necessary to meet parametric normality assumptions) (GMAV 5 for 
Windows $\left.{ }^{\circledR}\right)$ (Underwood, 2005). Student-Newman-Keuls (SNK) tests were used to isolate differences between sites or time (weeks).

195

\section{RESULTS}

Fluorescence spectrophotometry of diluted crab urine revealed significant PAH exposure characterised by strong fluorescence signals for both petrogenic and pyrogenic PAHs from both indigenous and deployed (caged crabs).

No differences were observed between crabs caught from the different sites with regard to Naphthalene-type metabolites (Fig. 2A), however, significant differences were observed between sites with both PYR and BAP-type metabolites significantly higher in urine from Gibraltar Harbour crabs than Palmones Estuary or Cadiz (reference) crabs $\left(F_{2,21}=49.77, P<0.001\right.$ and log-transformed $F_{2,21}=32.89$, $P<0.001$, for PYR- and BAP-type metabolites, respectively) (Fig. 2B and C). No differences in levels in any of the three PAH metabolite groups were observed between Palmones Estuary or Cadiz collected crabs. Physiological assessment of shore crabs collected from each site revealed that both Palmones Estuary and Gibraltar Harbour crabs were impacted as demonstrated by lower basal heart rates (log-transformed; $\left.F_{2,21}=35.73, P<0.001\right)(F i g .3 A)$ and lower neutral red retention times $\left(F_{2,21}=450.19, P<0.001\right)($ Fig. 3B) than Cadiz (reference) crabs.

215 The investigation of the Bay of Algeciras (Palmones Estuary) and Gibraltar Harbour sites using caged crabs demonstrated the presence of PAHs (NAPs and BAPs) as observed in shore crab urine (Table 1). High levels were recorded for all PAH metabolite types, especially PYR as significantly high concentrations (approx 125 $160 \mu \mathrm{g} \mathrm{I}^{-1}$ ) were observed in Palmones Estuary crabs (Fig. 4A) over the 8 week period $\left(F_{5,42}=3.70, P<0.01\right)$. Significantly high PYR concentrations $\left(153-221 \mu \mathrm{gl}^{-1}\right)$ 
were also observed continuously in Gibraltar Harbour crabs (Coaling Island) $\left(F_{5,42}=\right.$ 4.01, $P<0.01$ ). (Fig. 4B), however, in the inner harbour site high levels were observed initially with a subsequent return to background levels (Fig. 4C) (logtransformed; $\left.F_{5,42}=4.41, P<0.01\right)$. A ratio between 4 \& 5 ring PAHs \& 2-3 ring PAHs $\left(\mathrm{FF}_{\mathrm{BAP}+\mathrm{PYR}} / \mathrm{FF}_{\mathrm{NAP}}\right)$ was calculated in order to determine PAH contamination source (Table 2). Over the 8 week monitoring period, PAH contamination shifted from pyrogenic origin (due to high levels of PYR and BAP metabolites) (week 1) to petrogenic as observed in Gibraltar middle harbour site (week 8). The high levels of PYR and BAP metabolites also found in Palmones Estuary crabs indicate PAHs from a pyrogenic source (weeks 4) (Table 2). The observed variations in PAH levels in urine were also associated with significant physiological and cellular alterations. Physiological assessments revealed a significant acute reduction (approx. 50\%) in heart rates in crabs from all sites (at rest) at week 1 compared with controls (week 0 ) (two-way ANOVA; $F_{10,126}=2.51, P<0.001$ ) (Fig. 5A). Significant impacts at the cellular level were observed with significant reductions in neutral red retention times with the biggest reduction between week 0 and 1 . Although, reductions in neutral red retention times were observed in all sites over the 8 week monitoring period, significant differences were also observed between sites with Palmones Estuary crabs displaying significantly higher NRR times compared to both Gibraltar Harbour sites (weeks 1-4) (two-way ANOVA; $F_{10,126}=6.20, P<0.001$ ) (Fig. 5B).

\section{DISCUSSION}

Results from fluorescence spectroscopy indicates the presence of PAH metabolites at the sample sites characterised by strong $\mathrm{PAH}$-associated fluorescence responses at specified wavelengths. Shore crabs caught from each site revealed inter-site variation with significant differences occurring between both Cadiz and Palmones 
Estuary crabs and Gibraltar harbour crabs, where high levels of urinary PAH were observed. The observed high levels of PAH metabolites verify the fact that Gibraltar Harbour has a greater amount of boating and harbour activity due in large part the presence of the Naval Base and dockyard when compared to San Fernando, Cadiz, where there is relatively less boating activity. Cadiz was chosen as a reference site even though a low level of metabolites was detected. Pyrene metabolite concentrations in urine are approximately $30 \%$ higher than that of the parent compound in seawater (when exposed continuously) (Dissanayake et al., 2008a) and reflect short-term exposure (upto 4 days) rather than bioaccumulation (Watson et al., 2004b). Mean concentrations of pyrene found here (Cadiz, $20 \mathrm{\mu g} \mathrm{I}^{-1}$; Palmones, 13 $\mu \mathrm{g} \mathrm{I}^{-1}$ and Gibraltar Harbour $51 \mathrm{\mu gl}^{-1}$ ) are consistent with values found in relatively clean coastal sites $\left(17-20 \mu \mathrm{gl}^{-1}\right)$ and PAH contaminated sites $\left(40-90 \mu \mathrm{g} \mathrm{I}^{-1}\right)$ (Watson et al., 2004a; Dissanayake et al., 2010).

The mobility of PAHs due to both aqueous and aerial transport makes it difficult also to locate completely 'pristine' locations, although the Bay of Cadiz has been classed as a 'clean' area due to undetectable levels of PAHs in sediments (Riba et al., 2004). Other studies have also shown low metabolite levels present in various crustacean and fish species taken from areas assumed to be 'clean' (Klumpp et al., 2002; Eickhoff et al., 2003b; Ruddock et al., 2003; Dissanayake and Galloway, 2004). The similarity of metabolite levels found in indigenous populations of crabs from the reference site (Cadiz) and the intermediate Palmones Estuary may only reflect the bio-available water-borne PAH levels, however, previous studies have shown that the Palmones Estuary has high PAHs levels in sediments $641-725 \mathrm{mg} \mathrm{kg}^{-1}$ (MoralesCaselles et al., 2008; Ramos-Gómez et al., 2009). High levels of all PAH metabolites were observed in the Palmones Estuary over the 8 week monitoring period, which 275 was unexpected and may be largely attributed to a reported minor oil spill in the area over the background of a low level boating activity (inferred by the levels of NAP 
metabolites and low calculated pyrene concentrations in seawater). The presence of 4-ringed PAHs can also be inferred due to the elevated pyrene concentrations. The high $\mathrm{FF}_{\mathrm{BAP}+\mathrm{PYR}} / \mathrm{FF}_{\mathrm{NAP}}$ ratios, especially at week 4 (13.02) compared to control levels (4.87), indicates that the source of the PAHs may have been pyrogenic through the dominance of 4- and 5- ringed PAHs (Table 2b). Indigenous sampled crabs, however, demonstrated that Palmones Estuary-caught crabs indicated PAHs of a petrogenic origin (Table 2a), thereby indicating a change in the $\mathrm{PAH}$ origin over the study period. It could be argued that the pattern observed here (of increasing and decreasing levels PAH metabolites levels) may occur due to possible downregulation dose-dependent effects (thus reflecting environmental levels) or saturation processes of the biotransformation system. A previous study has shown that in Carcinus, when exposed to a set concentration similar metabolite levels are observed after 7 and 14 days exposure to a sustained dose $\left(200 \mu \mathrm{g} \mathrm{I}^{-1}\right.$ for 7 and 14 days exposure; see Dissanayake et al. 2008a). However, saturation processes of the biotransformation (mixed function oxidase) system may occur with high doses as observed by bell-shaped dose response curves as shown in vertebrate systems (Bosveld et al. 2002; Lu et al. 2009). In shore crabs, however, there is conflicting evidence for saturation of the biotransformation system as shown by Fossi et al. (2000) evaluated by measuring both benzo(a)pyrene monooxygenase activity and ethoxyresoru®n-O-deethylase activity (EROD) in both hepatopancreas and gills and remains to be tested. In this study, however, the pattern observed of increasing pyrene metabolite levels (weeks $1-8$ ) as seen in the Palmones Estuary deployed crabs (Fig. 4a) does not suggest saturation of the biotransformation system and thus may reflect exposure levels.

The results from this study indicate the effectiveness of using fluorescence spectrophotometry as a rapid, cost-effective technique for the detection of $\mathrm{PAH}$ exposure in field situations in tandem with physiological assessments to assess 
biological impact, especially in large coastal bays. By extrapolating the pyrene concentrations from the metabolite concentrations, the use of the FF method when used on urine represents a very useful tool indeed as it facilitates PAH temporal monitoring. External control sites have therefore limited importance benchmarking environmental concentrations as each site or location can be used as an 'internal' control. The objective of rapid screening techniques is to be able to discriminate between sites of varying contamination, thereby providing a rapid assessment of pollution (Galloway et al., 2002). The $\mathrm{FF}_{\mathrm{BAP}+\mathrm{PYR}} / \mathrm{FF}_{\mathrm{NAP}}$ ratio was used in order to indicate the source of PAH contamination (Aas et al., 2000a). The rationale for using this technique is based on the fact that PAHs occur in combination and PAH profiles (e.g. ratio of high to low molecular weight PAHs) can indicate sources of PAHs (Law and Biscaya, 1994; Wang et al., 2000). The FF technique is regarded as a measure of groups of $\mathrm{PAH}$ metabolites due to the incorporation of fluorescence contributions of other PAH compounds, such as chrysene, which fluoresces at both naphthalene \& pyrene wavelength pairs (Aas et al., 2000a). It is recognised that $\mathrm{FF}_{290 / 335}$ comprises mainly $2 \& 3$ ringed PAHs and 4 \& 5 ring PAHs for wavelength pairs $\mathrm{FF}_{341 / 383}$ \& $\mathrm{FF}_{380 / 430}$ respectively. Any monitoring programme which includes $\mathrm{FF}$ as a rapid screening technique for $\mathrm{PAH}$ exposure will, therefore, highlight the most frequent and prioritised $\mathrm{PAH}$ compounds associated with environmental monitoring (Aas et al., 2000a; MSC-E, 2001). The differences observed in PAH sources (pyrogenic and petrogenic) among the three deployment sites over time may also occur either by minor oil spills or from bunkering activities, characterised by high molecular weight PAHs (i.e. 4-5 ringed), or light engine fuels (low molecular weight PAHs; $2-3$ ringed) and /or the atmospheric emissions of an oil refinery in the vicinity, which remains to be tested. PAH emissions are distributed via the atmosphere over a large area and its fate is dictated by and dependant on wind direction (Eickhoff et al., 2003a). Inputs from non-point sources such as atmospheric deposition and from roads would be diffuse and pollutants would be quickly dispersed in the water column and local 
currents and/or dredging activities may have an effect on suspended matter levels (Zhou et al. 1998; Rogers, 2002; King et al., 2004). The atmosphere can be classed as a secondary dominant source of hydrocarbons in areas where the marine input is the primary dominant source (Zhou et al., 1996). In the context of environmental monitoring, it is therefore imperative that all modes of PAH inputs are evaluated, not only oil spills. PAH spectrofluorimetric analysis in crustacean urine and associated physiological assessments are therefore an integrated approach which represents a realistic, relatively-inexpensive means of monitoring the bioavailability of PAHs (Dissanayake and Galloway, 2004; Galloway et al., 2004; Watson et al., 2004a; 2004b). The potential for PAH-induced biological impact, or specifically, cellular stress, as observed here by reduced lysosomal dye retention times corroborates previous evidence of reduced retention times with contaminant exposure (Nicholson et al. 1999; Brown et al. 2004). Previous evidence of PAH-induced physiological effects includes tachycardia (increased heart rates) (Bamber \& Depledge 1997; Fossi et al. 2000; Camus et al. 2002; Dissanayake et al. 2008b) with acute exposure. In this study, however, only bradycardia (depressed heart rates) was observed and is indicative of chronic PAH exposure (Hagger et al. 2009).

A key facet of the urinary PAH metabolite technique is its ability to identify $\mathrm{PAH}$ 'hotspots' within relatively large coastal areas impacted by PAH contamination which promotes its use in environmental management and regulation procedures. The PAH metabolite technique has been used successfully in various decapod crustaceans (Watson et al. 2004a; Eickhoff 2003a; Koenig et al. 2008). Implementation of the PAH metabolite technique, when used especially in deployed (caged) crabs, and in conjunction with other biological techniques, allows for contaminant-induced physiological impact to be monitored temporally and therefore can be used as important tools in environmental monitoring schemes (Galloway et al. 2002, 2004). In summary, this study highlights the use of fluorescence 
spectrophotometry as a rapid, cost-effective biomonitoring tool of environmental contamination. Rapid screening techniques should therefore be incorporated with other physiological techniques (as shown here) as a means of primary modes of investigation within a framework of detailed investigative monitoring procedures, prior to mitigatory action being undertaken (Galloway et al., 2002; 2004).

\section{Acknowledgements}

We thank the Royal Navy Dive Team for shore crab collection (HMS Naval Base) and the Queen's Harbour Master for sampling permission. We thank Darren Torres and Neil Perera for logistical assistance. We thank also the University of Cadiz (T.A del Valls), University of Sevilla (J. C. Garcia-Gomez) and Gibraltar Museum (Darren Fa) for use of laboratory facilities. Project financial support by grants from Gibraltar Government Ministry of Education (educational grant) and University of Plymouth (Erasmus exchange grant) awarded to AD.

Aas, E., Baussant, T., Balk, L., Liewenborg, B. and Andersen, O.K., 2000a. PAH metabolites in bile, cytochrome P4501A and DNA adducts as environmental risk parameters for chronic oil exposure: a laboratory experiment with Atlantic cod. Aquatic Toxicology, 51(2), 241-258.

Aas, E., Beyer, J. and Goksoyr, A., 2000b. Fixed wavelength fluorescence (FF) of bile as a monitoring tool for polyaromatic hydrocarbon exposure in fish: an evaluation of compound specificity, inner filter effect and signal interpretation. Biomarkers, 5(1), 9-23.

Aas, E., Beyer, J., Jonsson, G., Reichert, W.L. and Andersen, O.K., 2001. Evidence of uptake, biotransformation and DNA binding of polyaromatic hydrocarbons in Atlantic cod and corkwing wrasse caught in the vicinity of an aluminium works. Marine Environmental Research, 52(3), 213-229.

Bamber, S.D. and Depledge, M.H., 1997. Responses of shore crabs to physiological challenges following exposure to selected environmental contaminants. Aquatic Toxicology, 40(1), 7992.

Beyer, J., Sandvik, M., Hylland, K., Fjeld, E., Egaas, E., Aas, E., Skare, J.U. and Goksoyr, A., 1996. Contaminant accumulation and biomarker responses in flounder (Platichthys flesus L.) and Atlantic cod (Gadus morhua L.) exposed by caging to polluted sediments in Sorfjorden, Norway. Aquatic Toxicology, 36(1-2), 75-98. an aluminium works evaluated by transplant caging and biliary fluorescence measurements of Atlantic cod (Gadus morhua L.). Marine Environmental Research, 46(1-5), 233-236. 
Bosveld, A.T.C., de Bie, P.A.F., van den Brink, N.W., Jongepier, H. and Klomp, A.V., 2002. In vitro EROD induction equivalency factors for the 10 PAHs generally monitored in risk assessment studies in The Netherlands. Chemosphere, 49(1), 75-83.

Brown, R.J., Galloway, T.S., Lowe, D., Browne, M.A., Dissanayake, A., Jones, M.B. and Depledge, M.H., 2004. Differential sensitivity of three marine invertebrates to copper assessed using multiple biomarkers. Aquatic Toxicology, 66(3), 267-278.

Camus, L., Jones, M.B., Borseth, J.F., Regoli, F. and Depledge, M.H., 2002. Heart rate, respiration and total oxyradical scavenging capacity of the Arctic spider crab, Hyas araneus, following exposure to polycyclic aromatic compounds via sediment and injection. Aquatic Toxicology, 61(1-2), 1-13.

Carballo, J.L., Naranjo, S.A. and García- Gómez, J.C., 1996. Use of marine sponges as stress indicators in marine ecosystems at Algeciras Bay (southern Iberian Peninsula). Marine Ecology Progress Series., 135, 109-122.

Castro, M., Santos, M.M., Monteiro, N.M. and Vieira, N., 2004. Measuring lysosomal stability as an effective tool for marine coastal environmental monitoring. Marine Environmental Research, Twelfth International Symposium on Pollutant Responses in Marine Organisms, 58(2-5), 741745.

Cesar, A., Choueri, R.B., Riba, I., Morales-Caselles, C., Pereira, C.D.S., Santos, A.R., Abessa, D.M.S. and DelValls, T.A., 2007. Comparative sediment quality assessment in different littoral ecosystems from Spain (Gulf of Cadiz) and Brazil (Santos and Sao Vicente estuarine system). Environment International, 33(4), 429-435.

Clarke, R.B., Frid, C. and Attrill, M.J., 2001. Marine Pollution, 5. Oxford University Press, Oxford.

Crothers, J.H., 1967. The biology of the shore crab Carcinus maenas (L). 1. The background anatomy, growth and life history. Field Studies, 2, 407-434.

Depledge, M.H. and Andersen, B.B., 1990. A computer-aided physiological monitoring-system for continuous, long-term recording of cardiac activity in selected invertebrates. Comparative Biochemistry and Physiology a-Physiology, 96(4), 473-477.

Dissanayake, A. and Galloway, T.S., 2004. Evaluation of fixed wavelength fluorescence and synchronous fluorescence spectrophotometry as a biomonitoring tool of environmental contamination. Marine Environmental Research, 58(2-5), 281-285.

Dissanayake, A., Galloway, T.S. and Jones, M.B., 2008a. Nutritional status of Carcinus maenas (Crustacea: Decapoda) influences susceptibility to contaminant exposure. Aquatic Toxicology, 89, 40-46.

Dissanayake, A., Galloway, T.S. and Jones, M.B., 2008b. Physiological responses of juvenile and adult shore crabs Carcinus maenas (Crustacea: Decapoda) to pyrene exposure. Marine Environmental Research, 66, 445-450.

Dissanayake, A., Piggott, C., Baldwin, C. and Sloman, K.A., 2010. The effects of sublethal contaminant exposure on foraging behaviour in the shore crab Carcinus maenas (Crustacea: Decapoda). Aquatic Toxicology, Submitted.

Eickhoff, C.V., Gobas, F. and Law, F.C.P., 2003a. Screening pyrene metabolites in the hemolymph of dungeness crabs (Cancer magister) with synchronous fluorescence spectrometry: Method development and application. Environmental Toxicology and Chemistry, 22(1), 59-66.

Eickhoff, C.V., He, S.X., Gobas, F. and Law, F.C.P., 2003b. Determination of polycyclic aromatic hydrocarbons in dungeness crabs (Cancer magister) near an aluminum smelter in Kitimat Arm, British Columbia, Canada. Environmental Toxicology and Chemistry, 22(1), 50-58.

Fillmann, G., Watson, G.M., Francioni, E., Readman, J.W. and Depledge, M.H., 2002. A nondestructive assessment of the exposure of crabs to PAH using ELISA analyses of their urine and haemolymph. Marine Environmental Research, 54(3-5), 823-828.

Fossi, M.C., Leonzio, C. and Peakall, D.B., 1994. The use of nondestructive biomarkers in the hazard assessments of vertebrate populations. In: M.C. Fossi and C. Leonzio (Editors), Non destructive Biomarkers in Vertebrates. Lewis Publishers, Boca Raton, Florida., pp. 3-34.

Fossi, M.C., Casini, S., Savelli, C., Corbelli, C., Franchi, E., Mattei, N., Sanchez-Hernandez, J.C., Corsi, I., Bamber, S. and Depledge, M.H., 2000. Biomarker responses at different levels of biological organisation in crabs (Carcinus aestuarii) experimentally exposed to benzo(alpha)pyrene. Chemosphere, 40(8), 861-874. M.H., 2002. Rapid assessment of marine pollution using multiple biomarkers and chemical immunoassays. Environmental Science \& Technology, 36(10), 2219-2226. 
Galloway, T.S., Brown, R.J., Browne, M.A., Dissanayake, A., Lowe, D., Jones, M.B. and Depledge, M.H., 2004. A multibiomarker approach to environmental assessment. Environmental Science \& Technology, 38(6), 1723-1731.

Hagger, J.A., Galloway, T.S., Langston, W.J. and Jones, M.B., 2009. Application of biomarkers to assess the condition of European Marine Sites. Environmental Pollution, 157(7), 2003-2010.

Jimenez-Tenorio, N., Salamanca, M.J., Garcia-Luque, E., Gonzalez de Canales, M.L. and DelValls, A., 2008. Chronic bioassay in benthic fish for the assessment of the quality of sediments in different areas of the coast of Spain impacted by acute and chronic oil spills. Environmental Toxicology, 23(5), 634-642.

Kennish, M.J., 2002. Environmental threats and environmental future of estuaries. Environmental conservation, 29(1), 78-107.

King, A.J., Readman, J.W. and Zhou, J.L., 2004. Dynamic behaviour of polycyclic aromatic hydrocarbons in Brighton marina, UK. Marine Pollution Bulletin, 48(3-4), 229-239.

Klumpp, D.W., Hong, H.S., Humphrey, C., Wang, X.H. and Codi, S., 2002. Toxic contaminants and their biological effects in coastal waters of Xiamen, China. I. Organic pollutants in mussel and fish tissues. Marine Pollution Bulletin, 44(8), 752-760.

Koenig, S., Savage, C. and Kim, J.P., 2008. Non-destructive assessment of polycyclic aromatic hydrocarbon $(\mathrm{PAH})$ exposure by fluorimetric analysis of crab urine. Marine Pollution Bulletin, 56(12), 2003-2008.

Krahn, M.M., Myers, M.S., Burrows, D.G. and Malins, D.C., 1984. Determination of metabolites of xenobiotics in the bile of fish from polluted waterways. Xenobiotica, 14,(8,), 633-646.

Law, R.J. and Biscaya, J.L., 1994. Polycyclic Aromatic-Hydrocarbons (PAH) - Problems and progress in sampling, analysis and interpretation. Marine Pollution Bulletin, 29(4-5), 235-241.

Livingstone, D.R., 1992. Persistent Pollutants in Marine Invertebrates. In: C.H.a.L. Walker, D.R. (Editor), Persistent Pollutants in Marine Ecosystems. Pergamon Press., Oxford.

Livingstone, D.R., 1998. The fate of organic xenobiotics in aquatic ecosystems: quantitative and qualitative differences in biotransformation by invertebrates and fish. Comp. Biochem. Phys.

490 A, 120, 43-49.

Lowe, D.M. and Pipe, R.K., 1994. Contaminant induced lysosomal membrane damage in marine mussel digestive cells - an in-vitro study. Aquatic Toxicology, 30(4), 357-365.

Lowe, D.M., Soverchia, C. and Moore, M.N., 1995. Lysosomal membrane responses in the blood and digestive cells of mussels experimentally exposed to fluoranthene. Aquatic Toxicology, 33(2), 105-112.

Lu, G., Wang, C. and Zhu, Z., 2009. The dose-response relationships for EROD and GST induced by polyaromatic hydrocarbons in Carassius auratus. Bulletin of Environmental Contamination and Toxicology, 82(2), 194-199.

Mavor, J.W.J., 1980. Ship traffic through the Gibraltar Strait. Journal of Navigation,, 33(3), 408-417.

Moore, M.N., Lowe, D.M. and Kohler, A., 2004. Biological effects of contaminants: Measurement of lysosomal membrane stability ICES Techniques in Marine Environmental Sciences. (No. 36).

Morales-Caselles, C., Martin Diaz, M.L., Riba, I., Sarasquete, C. and DelValls, T.A., 2008. Sublethal responses in caged organisms exposed to sediments affected by oil spills. Chemosphere, 72(5), 819-825.

505 MSC-E, 2001. Polycyclic aromatic hydrocarbon emmision inventories and emission expert estimates, MSC-E,.

Naes, K., Knutzen, J. and Berglind, L., 1995. Occurrence of PAH in marine organisms and sediments from smelter discharge in Norway. Science of the Total Environment, 163, 93-106.

510 (Bivalvia : Mytilidae). Marine Pollution Bulletin, 38(12), 1157-1162.

Perez, E., Blasco, J. and Sole, M., 2004. Biomarker responses to pollution in two invertebrate species: Scrobicularia plana and Nereis diversicolor from the Cadiz bay (SW Spain). Marine Environmental Research, 58(2-5), 275-279.

Ramos-Gómez, J., Martín-Díaz, M. and DelValls, T., 2009. Acute toxicity measured in the amphipod Ampelisca brevicornis after exposure to contaminated sediments from Spanish littoral. Ecotoxicology, 18(8), 1068-1076.

Reeves, W.R., McDonald, T.J., Cizmas, L. and Donnelly, K.C., 2004. Partitioning and desorption behavior of polycyclic aromatic hydrocarbons from disparate sources. Science of the Total Environment, 332(1-3), 183-192.

520 Riba, I., Forja, J.M., Gomez-Parra, A. and DelValls, T.A., 2004. Sediment quality in littoral regions of the Gulf of Cadiz: a triad approach to address the influence of mining activities. Environmental Pollution, 132(2), 341-353. 
Rogers, H.R., 2002. Assessment of PAH contamination in estuarine sediments using the equilibrium partitioning-toxic unit approach. Science of the Total Environment, 290(1-3), 139-155.

Ruddock, P.J., Bird, D.J., McEvoy, J. and Peters, L.D., 2003. Bile metabolites of polycyclic aromatic hydrocarbons (PAHs) in European eels Anguilla anguilla from United Kingdom estuaries. Science of the Total Environment, 301(1-3), 105-117.

Smith, V.J. and Ratcliffe, N.A., 1978. Host defence reactions of the shore crab, Carcinus maenas (L.), in vitro. J. Mar. Biol. Assoc. U.K, 58(367-379).

530 Stagg, R.M., 1998. The development of an international programme for monitoring the biological effects of contaminants in the OSPAR convention area. Marine Environmental Research, 46(1-5), 307-313.

Truver, S.C., 1978. The United States and the Strait of Gibraltar., Delaware University, Newark College of Marine Studies. Marine Policy Reports.

535 Underwood, A.J., 2005. Experiments in Ecology: Their logical design and interpretation using analysis of variance. Cambridge University Press, Cambridge.

United Nations, 2009. Environment Statistics Country Snapshot: Gibraltar.

Wang, Z., Fingas, M., Landriault, M., Sigouin, L. and Lambert, P., 2000. Distribution of PAHs in burn residue and soot samples and differentiation of pyrogenic and petrogenic PAHs- the 1994 and 1997 mobile burn study. In: C. Song, C.S. Hsu and I. Mochida (Editors), Chemistry of Diesel Fuels. Applied Energy Technology Series. Taylor and Francis.

Watson, G.M., Andersen, O.K. and Depledge, M.H., 2002. A direct fluorimetric technique for the detection of PAH equivalents in crustacean urine and haemolymph: potential for use as an in situ biomarker of PAH exposure. Marine Environmental Research, 54, 829-851.

Watson, G.M., Andersen, O.K., Depledge, M.H. and Galloway, T.S., 2004a. Detecting a field gradient of PAH exposure in decapod crustacea using a novel urinary biomarker. Marine Environmental Research, 58(2-5), 257-261.

Watson, G.M., Andersen, O.K., Galloway, T.S. and Depledge, M.H., 2004b. Rapid assessment of polycyclic aromatic hydrocarbon (PAH) exposure in decapod crustaceans by fluorimetric analysis of urine and haemolymph. Aquatic Toxicology., 67(2), 127-142.

Zhou, J.L., Fileman, T.W., Evans, S., Donkin, P., Mantoura, R.F.C. and Rowland, S.J., 1996. Seasonal distribution of dissolved pesticides and polynuclear aromatic hydrocarbons in the humber estuary and humber coastal zone. Marine Pollution Bulletin, 32(8-9), 599-608.

Zhou, J.L., Fileman, T.W., Evans, S., Donkin, P., Llewellyn, C., Readman, J.W., Mantoura, R.F.C. and Rowland, S.J., 1998. Fluoranthene and pyrene in the suspended particulate matter and surface sediments of the Humber estuary, UK. Marine Pollution Bulletin, 36(8), 587-597. 
Table 1. Naphthalene-and benzo[a]pyrene-type metabolite fluorescence contributions (peak area mean \pm SE) from urine of deployed crabs (caged) over an 8 week monitoring period from Palmones Estuary and Gibraltar Harbour (middle and inner sites) ( $n=8)($ different letters denote statistical difference between weeks; same letters (e.g. ab) denote no statistical difference to either groups a or b).

\begin{tabular}{|c|c|c|c|c|c|c|}
\hline \multirow{2}{*}{$\begin{array}{c}\text { Site } \\
\text { Metabolite } \\
\text { type } \\
\end{array}$} & \multicolumn{2}{|c|}{ Palmones Estuary } & \multicolumn{2}{|c|}{ Gibraltar Harbour (middle) } & \multicolumn{2}{|c|}{ Gibraltar Harbour (inner) } \\
\hline & Week & Peak area & Week & Peak area & Week & Peak area \\
\hline \multirow{6}{*}{ 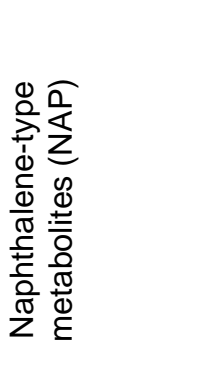 } & 0 & $2784 \pm 362^{a}$ & 0 & $2784 \pm 362^{a}$ & 0 & $2784 \pm 362^{a}$ \\
\hline & 1 & $4101 \pm 576^{c}$ & 1 & $5659 \pm 1175^{b}$ & 1 & $4635 \pm 500^{b}$ \\
\hline & 2 & $4817 \pm 716^{c}$ & 2 & $4480 \pm 286^{b}$ & 2 & $4627 \pm 337^{b}$ \\
\hline & 4 & $1742 \pm 86 b^{b}$ & 4 & $4020 \pm 287^{b}$ & 4 & $2897 \pm 182^{a}$ \\
\hline & 6 & $4016 \pm 202^{c}$ & 6 & $2109 \pm 345^{a}$ & 6 & $3027 \pm 185^{a}$ \\
\hline & 8 & $4488 \pm 322^{c}$ & 8 & $4625 \pm 528^{b}$ & 8 & $3469 \pm 367^{a b}$ \\
\hline $\begin{array}{l}\text { Statistical } \\
\text { difference }\end{array}$ & \multicolumn{2}{|c|}{$\mathrm{F}_{5,42}=13.82, P<0.001$} & \multicolumn{2}{|c|}{ log-transformed; $\mathrm{F}_{5,42}=4.82, P<0.01$} & \multicolumn{2}{|c|}{ log-transformed; $\mathrm{F}_{5,42}=6.25, P<0.001$} \\
\hline \multirow{6}{*}{ 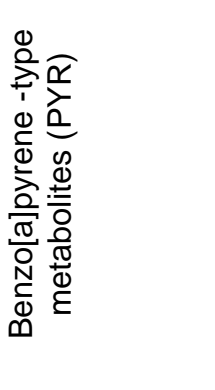 } & 0 & $4781 \pm 955^{a}$ & 0 & $4781 \pm 955^{a}$ & 0 & $4781 \pm 955^{a}$ \\
\hline & 1 & $10236 \pm 1739^{b}$ & 1 & $11570.19 \pm 2015^{c}$ & 1 & $9863 \pm 2065^{b}$ \\
\hline & 2 & $12110 \pm 1651^{b}$ & 2 & $12309 \pm 2614^{c}$ & 2 & $14766 \pm 2816^{b c}$ \\
\hline & 4 & $3668 \pm 761^{a}$ & 4 & $7679 \pm 1426^{b}$ & 4 & $6401 \pm 837^{a}$ \\
\hline & 6 & $11821 \pm 1310^{b}$ & 6 & $3183 \pm 977^{a}$ & 6 & $3760 \pm 839^{a}$ \\
\hline & 8 & $14093 \pm 2904^{b}$ & 8 & $10153 \pm 1454^{b c}$ & 8 & $8919 \pm 1713^{b}$ \\
\hline $\begin{array}{l}\text { Statistical } \\
\text { difference }\end{array}$ & \multicolumn{2}{|c|}{ log-transformed; $F_{5,42}=10.64, P<0.001$} & \multicolumn{2}{|c|}{ log-transformed; $F_{5,42}=7.22, P<0.001$} & \multicolumn{2}{|c|}{ log-transformed; $F_{5,42}=45.47, P<0.001$} \\
\hline
\end{tabular}


Table 2. $\mathrm{FF}_{\mathrm{BAP}+\mathrm{PYR}} / \mathrm{FF}_{\mathrm{NAP}}$ ratio as an indicator of $\mathrm{PAH}$ contamination in a) indigenous sampled populations and in b) deployed shore crabs $(n=8)$. PETRO (predominance of 2-3 ringed PAHs) indicates petrogenic contamination and PYRO (predominance of 4- and 5-ringed PAHs) indicates pyrogenic contamination (i.e. ratio values of $<4.87$ and $>4.87$, respectively, relative to that of the control site). Only the lowest (i.e. petrogenic) and highest (pyrogenic) ratios are indicated here.

$2 \mathrm{a}$

\begin{tabular}{ccc}
\hline & Site & \\
$\begin{array}{c}\text { Cadiz } \\
(\text { control })\end{array}$ & Palmones Estuary & Gibraltar Harbour \\
\hline
\end{tabular}

\begin{tabular}{lll}
4.87 & 3.95 PETRO & 36.14 PYRO \\
\hline \hline
\end{tabular}

$2 b$

\begin{tabular}{cccc}
\hline Week & $\begin{array}{c}\text { Palmones } \\
\text { Estuary }\end{array}$ & $\begin{array}{c}\text { Site } \\
\text { (middle) }\end{array}$ & $\begin{array}{c}\text { Gibraltar Harbour } \\
\text { (inner) }\end{array}$ \\
\hline 0 & 4.87 & 4.87 & 4.87 \\
1 & 5.87 & 7.42 & 5.90 \\
2 & 6.32 & 6.75 & 7.94 \\
4 & 13.02 PYRO & 7.54 & 7.99 \\
6 & 8.36 & 9.32 & 5.10 \\
8 & 7.62 & 8.81 & 6.05 \\
\hline \hline
\end{tabular}




\section{List of Figures}

Fig. 1. Map showing the location of sites (see insets) within the Southwest lberian Peninsula. Insets (1.) denote Cadiz (C) (relatively 'clean') (2) within the Bay of Algeciras (Palmones Estuary; P) and within Bay of Gibraltar (2a); Gibraltar Harbour inner (I) and middle $(\mathrm{m})$.

Fig. 2. Relative fluorescence contributions (peak area mean $\pm S E$ ) of each of the $P A H$ groups (A; NAP; naphthalene-type, B; PYR; pyrene-type and C; BAP; benzo[a]pyrene type in crabs caught from Cadiz, Palmones Estuary and Gibraltar Harbour $(n=8)$ (different letters denote statistical difference between sites; same letters denote no statistical difference).

Fig. 3. Shore crab physiological assessment (mean $\pm \mathrm{SE}$ ): $\mathrm{A}$; heart rate (at rest) and $\mathrm{B}$; neutral red retention time of crabs caught from Cadiz, Palmones Estuary and Gibraltar Harbour $(n=8)$ (different letters denote statistical difference between sites; same letters denote no statistical difference).

Fig. 4. Pyrene-type metabolite concentrations $\left(\mu \mathrm{gl}^{-1}\right)$ (mean $\pm \mathrm{SE}$ ) from urine of deployed (caged) crabs over an 8 week monitoring period from A; Palmones Estuary, B; Gibraltar Harbour middle and C; Gibraltar Harbour inner sites $(n=8)$ (different letters denote statistical difference between weeks; same letters denote no statistical difference).

Fig.5. Shore crab physiological assessment (mean mean $\pm \mathrm{SE}$ ): $A$; heart rate (at rest) and $B$; neutral red retention time of deployed (caged) crabs over an 8 week monitoring period from Palmones Estuary and Gibraltar Harbour (middle and inner sites) $(n=8)$ (different letters denote statistical difference between sites within each week; same letters denote no statistical difference). 


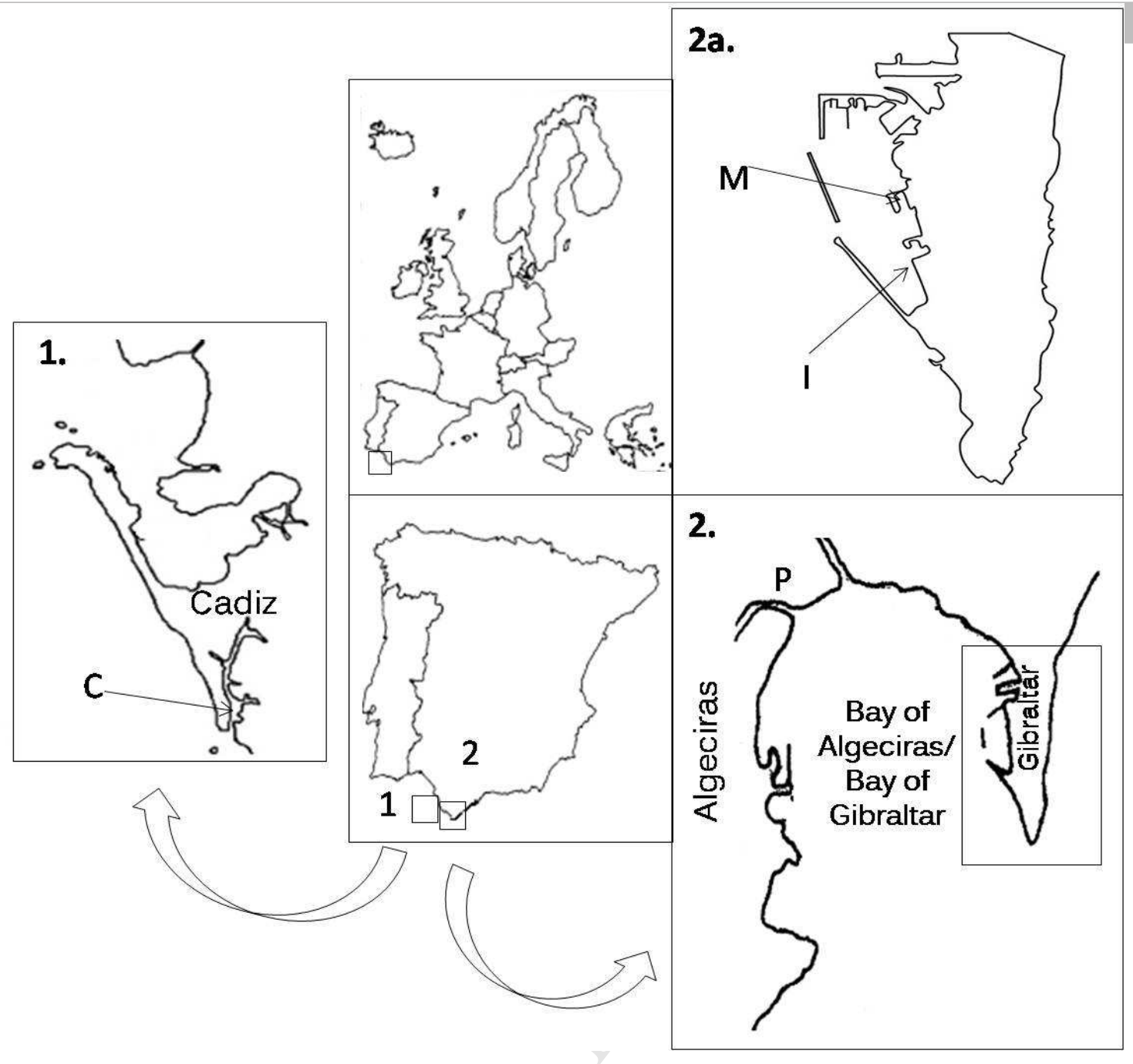

Fig. 1 

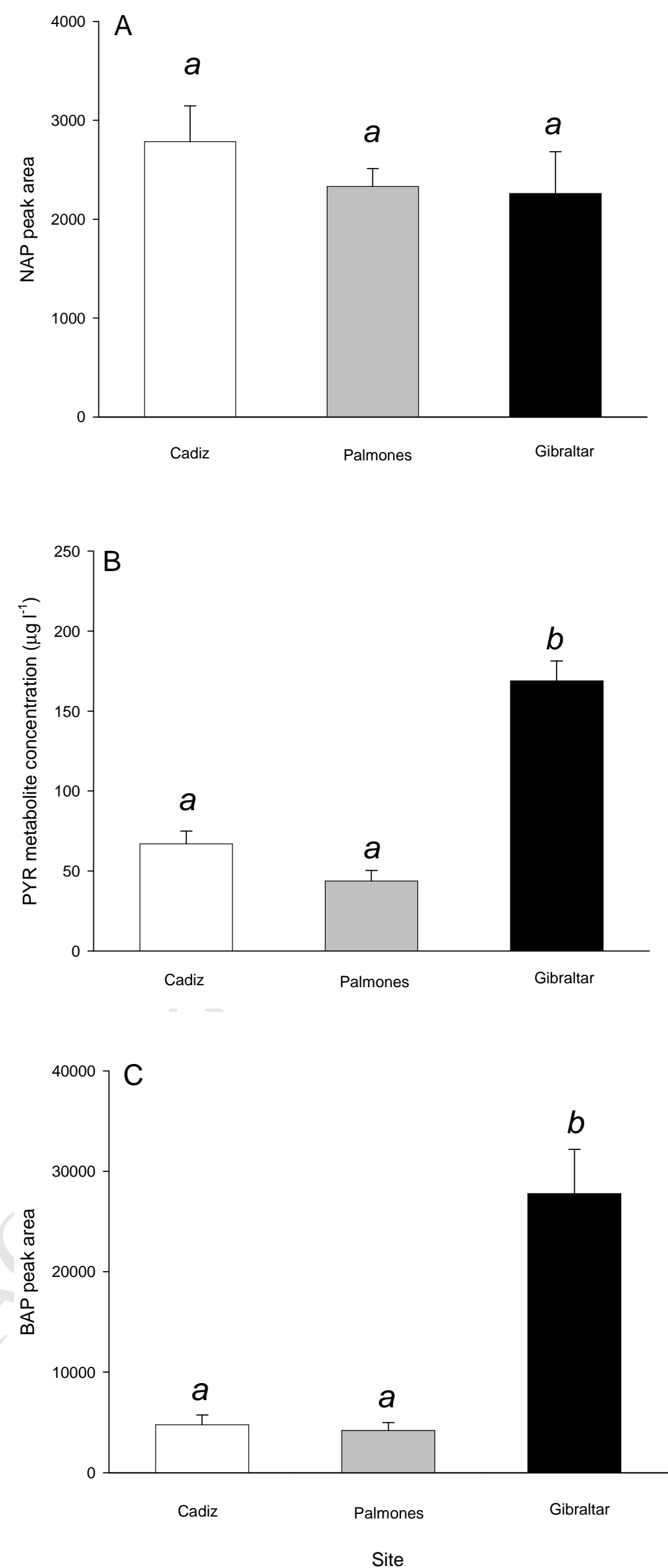

Fig. 2. 

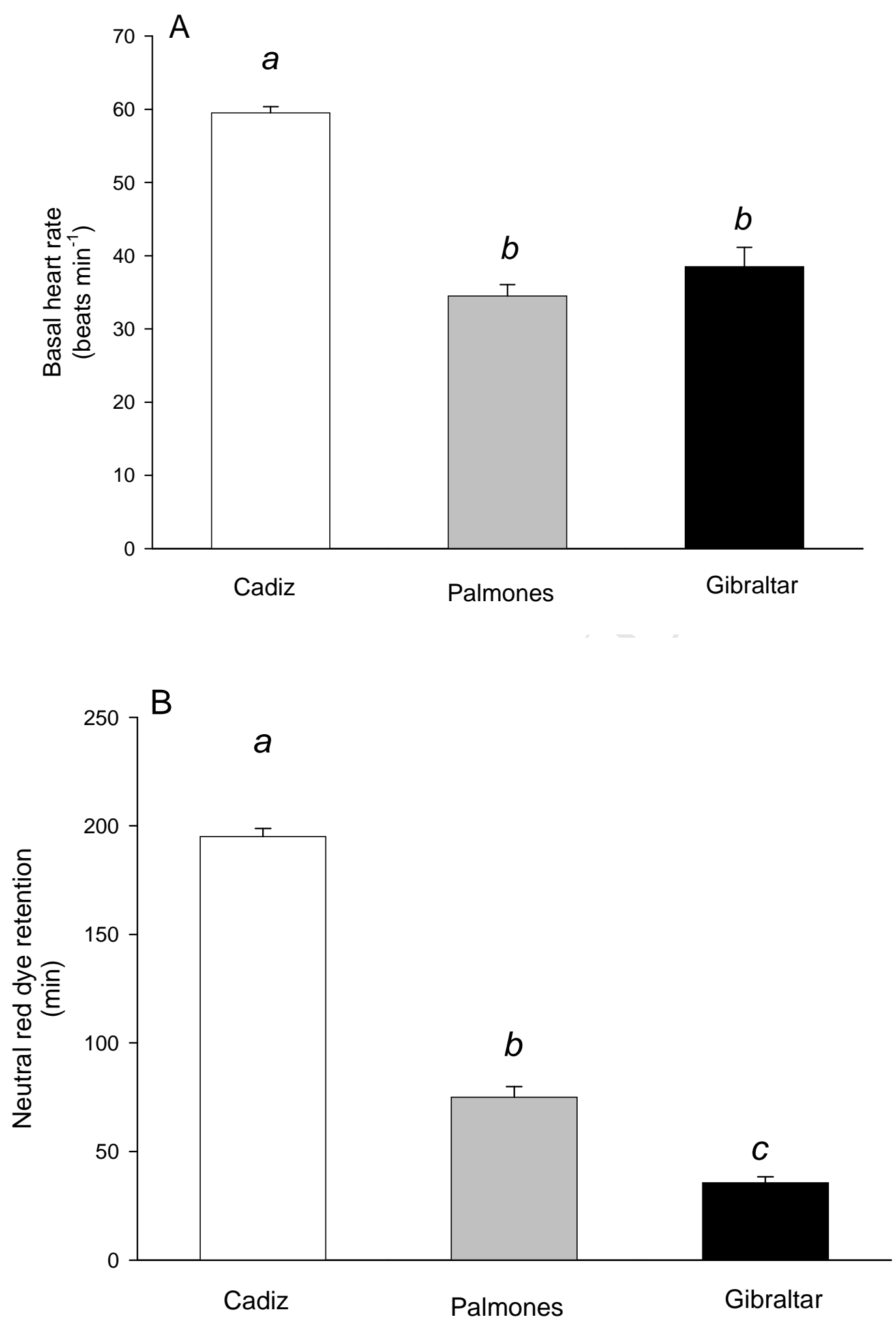

Site

Fig. 3. 

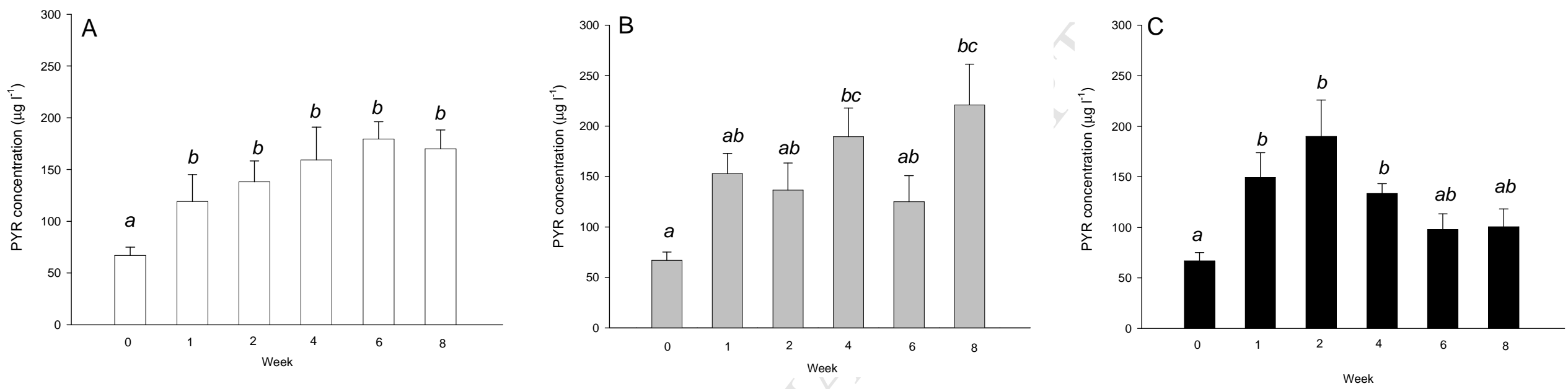

Fig. 4. 

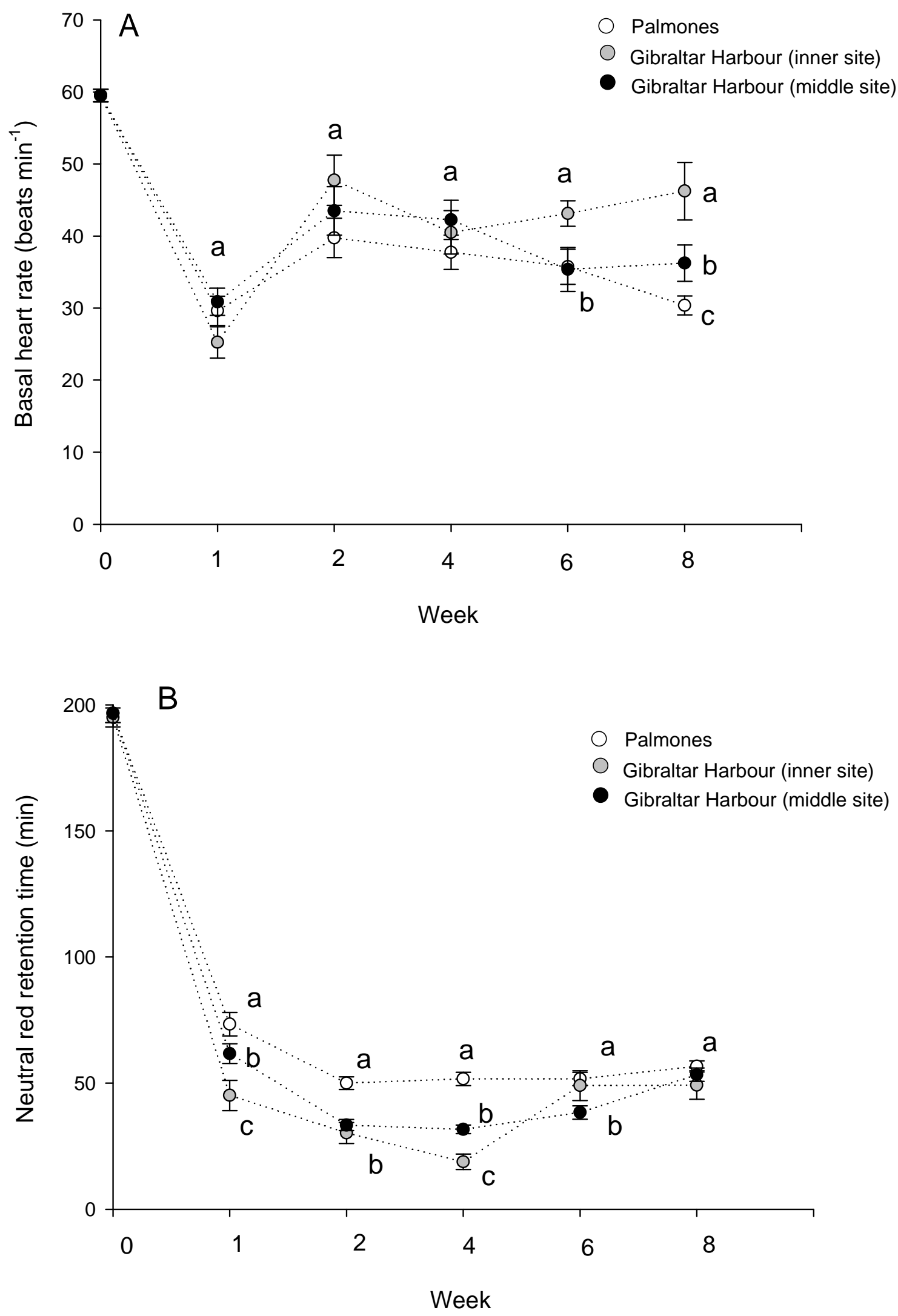

Fig. 5. 